\title{
TRANSITIVITY IN THE TENTH GRADE STUDENTS' RECOUNT TEXTS (A SYSTEMIC FUNCTIONAL GRAMMAR: SFG)
}

\author{
Sita Hediyati Rahayu ${ }^{1}$, Efransyah ${ }^{2}$ \\ ${ }^{1}$ IKIP Siliwangi \\ ${ }^{2}$ IKIP Siliwangi \\ ${ }^{1}$ sitarahayu17@gmail.com, ${ }^{2}$ efransbae@gmail.com
}

\begin{abstract}
This research aims to analyze the use of transitivity in the tenth grade students' recount text and to find out the types of processes that are mostly found in the text. The data are taken from five recount texts written by five groups of the tenth grade students in one of the senior high schools in Cimahi. The researchers used descriptive qualitative as the method of this research. From the whole data, the researchers found 69 clauses and those are divided into seven types of processes as stated by Halliday. After classifying them, the researchers only found six types of processes which are: material process found in 45 clauses $(65.2 \%)$, mental process found in 11 clauses $(16 \%)$, relational process found in 5 clauses $(7.2 \%)$, existential process found in 4 clauses $(5.8 \%)$, behavioral process found in 2 clauses (2.9\%) and verbal process found in 2 clauses $(2.9 \%)$. While meteorological process was not found in the data. The most commonly process found in the data was material process which consists of 45 clauses for the recount text was retelling something happened in the past which experienced by the students.
\end{abstract}

Keywords: Systemic Functional Grammar, Transitivity, Recount Text

\section{INTRODUCTION}

This research analyzed the application of Halliday's theory of transitivity in the tenth grade students' recount text. Transitivity is known as the system to explore the clause as representation. We can found the word 'Transitivity' in Systemic Functional Linguistic (SFL). Almurashi (2016) explained that SFL is a language approach developed by M. A. K. Halliday in the 1960s and SFL studies the language through meaning and its function. Gerot and Wignell (1995) as cited in Rohmat and Nurhaeni (2018) stated that language meaning in SFL is divided into three categories of metafunctions; ideational meaning which focused on main verb or express about phenomena, feeling and idea; interpersonal meaning which declare what speaker wants to speak up to others; and textual meaning which express how language being related to its environment. This paper aims to identify several recount texts that is created by the tenth grade students in terms of its ideational meanings which is described as Transitivity.

In transitivity system, Chamberlain (2016, p. 218) as cited in Senjawati (2016) stated that there are three main functional roles namely; participant, process and circumstance. Participants stated in Kurnia (2018) are involved of doing the process. Process is the action word or in Gerot and Wignell (1995) explained that processes are realized by verb. And circumstances answer such questions as when, where, why, how, etc. In traditional grammar, verb is defined as an action word. But in the functional grammar, some verbs are not only action or doing but also feeling, thinking, having are included in the verb or in functional grammar called as process. Processes are central in transitivity and those different types explained by Halliday. These types 
stated in Gerot and Wignell as material, behavioral, mental, verbal, relational, existential and meteorological.

Gerot and Wignell (1995) stated that material process is the process which some entities doing something physically. Participant in material process called as 'Actor' and the object in material process called as 'goal'. Behavioral process in Bustam (2011) explained as the process which almost similar with material and mental process while Salsabil (2014) stated as the process of physiological and psychological behavior. Participant in behavioral process called as 'Behaver'. Mental process in Ong'onda (2016) explained as the process of sensing, seeing, feeling and thinking while Arifiani stated that mental process is the person's conscious processing which include process of perception (perceiving through five sense), cognition (thinking) and affection (feeling). 'Senser' known as the participant of mental process and 'phenomenon' is that which is felt, thought or seen.

Marbun and Yanti (2016) stated that Verbal process is the process of saying and signaling but saying here covers any kind of symbolic exchange in a broad sense like reporting and quoting. The participant in verbal process is 'Sayer' while Gerot and Wignell explained that there are the other participants that may be occur in verbal process, 'Receiver' the person which Sayer spoke to, 'Target' one acted upon verbally (insulted, complimented, etc.), 'Range/Target' a name for the verbalization itself. Relational process is the process of being and having. Gerot and Wignell (1995) explained that they can be classified into two different categories, first they used to identify something which called 'Identifying Processes' and the second they used to assign a quality to something which called 'Attributive Processes'. In identifying processes, the participants are Token and Value while in attributive processes is Carrier and Attribute.

Existential process is the process of existence as explained in Salsabil (2014) that existential has only participant 'Existent'. Existential process is expressed by verbs of existing such be, exist and arise. and Meteorological process is the process of weathering which stated in Gerot and Wignell. This study focused on several recount texts written by the students. Based on the latest curriculum for senior high school or 2013 revised curriculum, the detail materials of recount text are delivered in the tenth grade including descriptive and narrative text (Kemendikbud, 2018). Hyland in Wulandari (2015) stated that recount text is the type of text to retell events for informing or entertaining. Mukarto in Salimah (2017) stated that there are three elements in the structure of recount text; (1) Orientation which introduces the background information of the story, (2) Series of Events which tells the events in chronological order, and (3) Re-Orientation which tells the ending of the story.

\section{METHOD}

This study used descriptive qualitative research as the method for collecting the data. Creswell (2009) stated that Qualitative research is a means for exploring and understanding the problem. In line with this, Taylor (1984) as cited in Efransyah (2020) stated that qualitative methods make researchers develop concepts, insights and understandings of the pattern in the data. The data in this research used recount texts created by the tenth grade students. The researchers conducted this research in one of the senior high school in Cimahi, Jawa Barat, Indonesia. In this study, the researchers focused on the how is the application of transitivity and which types of processes that are mostly found in the tenth grade students' recount text. Before collecting the data, the researchers had given the detail material about recount text to the students and they asked the students to make the recount text with their team. To collect the data, the researchers used several steps. The first one is analyzing the texts by its schematic structure. The second, 
dividing each sentence into clauses. Then, classifying those clauses into seven types of transitivity based on Halliday's theory as explained in Gerot and Wignell (1995). And finally, the researchers counted each process to find out the type of processes which mostly found in recount texts created by the students.

\section{RESULTS AND DISCUSSION}

\section{Results}

The result of the study from recount texts written by five groups of students in one of senior high school in Cimahi revealed as follows:

Table 1. Types of Processes in Students' Recount Text

\begin{tabular}{lccccc}
\hline $\begin{array}{l}\text { Types of } \\
\text { Processes }\end{array}$ & Text $\mathbf{1}$ & Text 2 & Text 3 & Text 4 & Text 5 \\
\hline Material & 8 & 10 & 8 & 7 & 12 \\
Behavioral & - & - & 2 & - & - \\
Mental & - & 1 & 5 & 2 & 3 \\
Verbal & 1 & - & - & 1 & - \\
Relational & 3 & - & 1 & 1 & - \\
Existential & - & - & 1 & 1 & 2 \\
Meteorological & - & - & - & - & - \\
\hline Total & 12 & 11 & 17 & 12 & 17 \\
\hline
\end{tabular}

From five recount texts written by the students, the researchers found 69 clauses which divided into 7 transitivity systems, namely material, behavioral, mental, verbal, relational, existential and morphological. From the table above, it can be seen that there are 3 kind of processes found in the first text, 2 kind of processes in the second text, 5 kind of processes in the third text, 5 kind of processes in the fourth text, and 3 kind of processes in the fifth text. From the seven types of processes, six processes are found in text. Morphological process was not found in the entire text analyzed. And the percentage of each process will be listed in the table below:

Table 2. Percentage of Each Process in Students' Recount Text

\begin{tabular}{lcc}
\hline $\begin{array}{l}\text { Types of } \\
\text { Processes }\end{array}$ & $\begin{array}{c}\text { Frequency of } \\
\text { Appearances }\end{array}$ & Percentages \\
\hline Material & 45 & $65.2 \%$ \\
Behavioural & 2 & $2.9 \%$ \\
Mental & 11 & $16 \%$ \\
Verbal & 2 & $2.9 \%$ \\
Relational & 5 & $7.2 \%$ \\
Existensial & 4 & $5.8 \%$ \\
Meteorological & - & - \\
\hline Total & 69 & $100 \%$ \\
\hline
\end{tabular}

From the table 2 shows that the most processes found in the recount texts written by the tenth grade students were material process which found $65.2 \%$ in the entire texts. The second most 
common type is mental process which found 16\%. The only type that is not found is the meteorological process. While the relational process found $7.2 \%$ in the texts and the existential process found in 4 clauses with $4 \%$. And the last is behavioral and verbal types were found in each 2 clauses of the entire texts.

\section{Discussion}

From the result of data finding above, the researchers interpreted them as explained below:

\section{Material Process}

From 69 clauses, the researchers found 45 clauses as the material process which is the most types of process found in the texts. They took some examples of material process to be analyzed as follow:

\section{Data 1}

\begin{tabular}{llll}
\hline We & ate & at a restaurant & together. \\
\hline Actor & Material & Circumstance: Place & Circumstance: \\
& & & Accompaniment
\end{tabular}

The clause above includes the type of material process, because the actor (we) is physically doing something (ate). The clauses above have 2 kind of circumstances; word 'at a restaurant' as a circumstance of place, because it shows 'where'. And word 'together' as a circumstance of accompaniment, because it shows 'with whom'.

\section{Data 2}

$$
\text { I brought many souvenirs typical of the Bogor city. }
$$

\section{Actor Material Goal}

The clause above includes the type of material process, because the actor $(I)$ physically doing something (brought). The word 'many souvenirs typical of the Bogor city' act as a goal, because as the direct object of the process.

\section{Data 3}

\begin{tabular}{lll}
\hline We & went & in the afternoon \\
\hline Actor & Material & Circumstance: Time
\end{tabular}

The clause above includes the type of material process, because the actor (we) physically doing something (went). And the word 'in the afternoon' acts as a circumstance of time, because it shows 'when'.

\section{Data 4}

\begin{tabular}{lll}
\hline We & walked & to the exit street. \\
\hline Actor & Material & Circumstance: Place
\end{tabular}

The clause above includes the type of material process, because the actor (we) physically doing something (walked). The word 'to the exit street' acts as a circumstance of place, because it shows 'where'. 


\section{Data 5}

\begin{tabular}{llll}
\hline I and my friends & went & to Jakarta & for holiday. \\
\hline Actor & Material & $\begin{array}{l}\text { Circumstance: } \\
\text { Place }\end{array}$ & Circumstance: Cause
\end{tabular}

The clause above includes the type of material process, because the actor ( $I$ and $m y$ friends) physically doing something (went). And the clauses above have 2 different circumstances; word 'to Jakarta' acts as a circumstance of place, because it shows 'where'. The word 'for holiday' acts as a circumstance of cause, because it tells the purpose of the process.

\section{Mental Process}

From 69 clauses, the researchers found 11 clauses as the mental process. There are three types of mental process; process of feeling (Affective) found in 5 clauses, process of thinking (Cognitive) found in 3 clauses and process of perceiving (Perceptive) found in 3 clauses. Some examples of mental process found in the text are:

\section{Data 6}

\begin{tabular}{llll}
\hline In the middle of the street, & we & were surprised & by many monkeys. \\
\hline Circumstance: Place & Senser & Mental: Affect & Phenomenon
\end{tabular}

The clause above includes the type of mental process, because the senser (we) feeling something or react to the something (surprised).

\section{Data 7}

\begin{tabular}{lll}
\hline We & thought & they didn't like us \\
\hline Senser & Mental: Cognitive & Phenomenon
\end{tabular}

The clause above includes the type of mental process, because the word 'thought' is the cognitive process or process of thinking.

\section{Relational Process}

From 69 clauses, the researchers found 5 clauses as the relational process. There are two types of relational process; process of giving attribute (Attributive) found in 2 clauses and process of indicate (Identifying) found in 3 clauses. Some examples of relational process found in the text are:

\section{Data 8}

\begin{tabular}{lll}
\hline Last Thursday & was & a busy day for me. \\
\hline Carrier & Attributive: & Attribute \\
& Intensive &
\end{tabular}

The clause above includes the type of relational process: attributive, because the word 'was' gives an attribute that the carrier (Last Thursday) be a busy day for me.

\section{Existential Process}

From 69 clauses, the researchers found 4 clauses as the existential process. In existential process, the word 'there' has no representational function. Some examples of existential process found in the text are:

\section{Data 9}

\begin{tabular}{llll}
\hline There & was & a waterfall & in Lembang \\
\hline & Existential & Existent & Circumstance: Place
\end{tabular}


The clause above includes the type of existential process. The word 'There' above has no representational meaning but tells that such $a$ waterfall is exists.

\section{Behavioral Process}

From 69 clauses, the researchers found 2 clauses as the behavioral process. Some examples of behavioral process found in the text are:

\section{Data 10}

\begin{tabular}{lll}
\hline Shouted & $u s$ & loudly. \\
\hline Behavioural & Range & Circumstance: \\
& & Manner
\end{tabular}

The clause above includes the type of behavioral process. The behaver in the clause above is included in the previous clause. And 'shouted' act as a behavioral process, because, it is the mental behavior of the behaver (monkey). And 'loudly' acts as a circumstance of manner, because it shows 'how'.

\section{Verbal Process}

From 69 clauses, the researchers found 2 clauses as the verbal process. Some examples of verbal process found in the text are:

\section{Data 11}

\begin{tabular}{llll}
\hline my mom & asked & me & to give some food for my neighbors. \\
\hline Sayer & Verbal & Receiver & Verbiage
\end{tabular}

The clause above includes the type of verbal process, because the word 'asked' acts as the signaling process verbally by the sayer (my mom). And the word ' $m e$ ' as the receiver, because it is the one to whom the process is addressed. The words 'give some food for my neighbors' is the verbiage or the name for the verbalization itself.

\section{CONCLUSION}

Based on the result and discussion above, the researchers concluded that six types of process were found in the data, which are material process, relational process, mental process, verbal process, existential process and behavioral process. Material process found in 45 clauses (65.2\%), mental process found in 11 clauses (16\%), relational process found in 5 clauses (7.2\%), existential process found in 4 clauses $(5.8 \%)$, behavioral process found in 2 clauses $(2.9 \%)$ and verbal process found in 2 clauses $(2.9 \%)$. The only type which is not occurred in the data was the meteorological process. Meanwhile the material process found as the most dominant types which occurred in the data for the recount text was retelling something happened in the past which experienced by the students.

\section{ACKNOWLEDGMENTS}

I would like to express my gratitude as much as possible to my supervisor, Mr. Efransyah and Mrs. Aseptiana who gave me a lot of attention, contribution and support in preparing this article. Furthermore, my deepest thanks to my beloved parents, for their prayers, advice, support, time and attention in completing this article. I also give special thanks to all my friends in the English Education Department for all the guidance and prayer so that I can complete this article. Finally, I also thank anyone who has made articles, research and books related to this article so that I can use them as a source for compiling my articles. I wrote this article with limitations as a 
student of the English Department of Education, but I hope this article can be used as a positive contribution to anyone who reads it.

\section{REFERENCES}

Almurashi, W. A. (2016). An Introduction To Halliday's Systemic Functional Linguistic. Macrothink Institute, Vol. 4, No. Https://Doi.Org/10.5296/Jsel.V4il.9423

Arifiani, F. R. (N.D.). Transitivity System In Reading Passage Of English Textbook For Junior High School. Jurnal Unimed.

Bustam, M. R. (2011). Analyzing Clause By Halliday’s Transitivity System. Jurnal Ilmu Sastra, Vol. 6, No.

Efransyah. (2020). Connotative Meaning In The Proverbs Of The Besemah Language ( A Sematic Study ). Project-Proffesional Journal Of English Education, 3(1), 143-148.

John W. Creswell. (2009). Research Design Qualitative, Quantitative, And Mixed Methods Approaches By John W. Creswell, 3rd, In 2009.Pdf (Third Edit).

Kurnia, D. (2018). The Transitivity Analysis Of Short Story No Withcraft For Sale By Doris Lessing. Walisongo State University Of Islamic Studies.

Linda Gerot And Peter Wignell. (1995). Making Sense Of Functional Grammar (An Introductory Workbook) (Reprinted). Printed In Australia: Gerd Stabler.

Marbun And Lidia April Yanti. (2016). Process Types Of Transitivity System In The National Geographic's Articles. The Episteme Journal Of Linguistic.

Ong'onda, N. A. (2016). Transitivity Analysis Of Newspaper Headlines On Terrorism Attack In Kenya: A Case Study Of Westgate Mall, Nairobi. Ijjhssnet.Com (International Journal Of Humanities And Social Science), Vol.6, No. Https://Doi.Org/Issn 2220-8488 (Print), 2221-0989 (Online)

Pendidikan, M., Kebudayaan, D. A. N., \& Indonesia, R. (2018). Jdih.Kemdikbud.Go.Id.

Rohmat, Nurhaeni, A. (2018). Transitivity Analysis Of Tenth Grade Students' Descriptive Text. Project-Proffesional Journal Of English Education, 01, No. 03.

Salimah, U. F. (2017). Improving Students Skills In Writing Recount Text By Using Manga Strips.

Salsabil, S. (2014). A Transitivity Analysis Of English Texts In Bahasa Inggris When English Rings The Bell. Yogyakarta State University.

Senjawati, D. (2016). Transitivity Analysis Of Tenth Grade Students ', 4(1), 1-22.

Wulandari, A. (2015). Improving Students' Vocabulary Used In Writing Recount Text By Using Word Ping Pong Game. 